Int. J. Dev. Biol. 57: 461-465 (2013)

doi: $10.1387 / \mathrm{ijdb} .130063 \mathrm{mv}$

\title{
Transgenic plants: from first successes to future applications
}

\author{
MIEKE VAN LIJSEBETTENS ${ }^{1,2, *}$, GEERT ANGENON ${ }^{3}$ and MARC DE BLOCK ${ }^{4}$ \\ ${ }^{1}$ Department of Plant Systems Biology, VIB, 9052 Gent, Belgium, ${ }^{2}$ Department of Plant Biotechnology and \\ Bioinformatics, Ghent University, 9052 Gent, Belgium, ${ }^{3}$ Institute for Molecular Biology and Biotechnology, Vrije \\ Universiteit Brussel, 1050 Brussels, Belgium and ${ }^{4}$ Bayer CropScience NV, Innovation Center, 9052 Gent, Belgium
}

\begin{abstract}
This dialogue was held between the Guest Editors of the Special Issue on "Plant Transgenesis" of the Int. J. Dev. Biol. and Marc De Block. He was one of the first scientists worldwide to obtain transgenic plants transformed with the chimeric selectable marker genes encoding neomycin phosphotransferase and bialaphos that confer resistance against the antibiotic kanamycin and the herbicide Basta ${ }^{\circledR} /$ glufosinate, respectively at the Department of Genetics of Ghent University and, later on, at the spin-off company, Plant Genetic Systems. Today, these two genes are still the most frequently utilized markers in transgene technology. Marc De Block chose to work on the improvement of crops in an industrial environment to help realize the production of superior seeds or products. He was part of the team that developed the male sterility/restorer system in canola (Brassica napus var. napus) that led to the first hybrid lines to be commercialized as successful products of transgene technology. In more than $\mathbf{3 0}$ years of research, he developed transformation procedures for numerous crops, designed histochemical, biochemical and physiological assays to monitor plant performance, and made original and innovative contributions to plant biology. Presently, he considers transgenic research part of the toolbox for plant improvement and essential for basic plant research.
\end{abstract}

KEY WORDS: neomycin phosphotransferase II gene (nptII), bialaphos resistance gene (bar), ribonuclease gene (barnase), canola, tobacco, potato, cotton

Marc De Blockwas born on October 25, 1955 in Beveren (Belgium), a small town in a rural area on the west bank of the river Schelde and approximately $15 \mathrm{~km}$ from Antwerpen. He studied Biology at the "Rijksuniversiteit Gent" (currently the "Universiteit Gent") and graduated with a Masters degree in 1977, Summa cum Laude. As a fellow of the "National Fonds voor Wetenschappelijk Onderzoek" (NFWO; the Belgian Foundation for Scientific Research), he obtained a PhD in Sciences in 1982 at the Department of Genetics under the promotership of the Professors Jozef Schell and Marc Van Montagu. The title of his PhD thesis was "The use of transposons for the mutagenesis and conjugation of the Ti plasmid of Agrobacterium tumefaciens". Subsequently, during his two-year NFWO postdoctoral fellowship at the Department of Genetics in Gent, he succeeded in making the first transgenic callus and plants transformed with chimeric selectable genes. In 1984, he joined the start-up company Plant Genetic Systems (PGS) to further develop the plant transformation technology. The PGS company was consecutively acquired by agronomical companies and, since 2002, is part of the Bayer CropScience Innovation Centre in Gent, where Marc De Block is currently appointed as an expert scientist. His research has been aimed at studying important agricultural traits, such as herbicide tolerance, male sterility, stress tolerance, and energy homeostasis by using physiological, biochemical, cell biological, molecular biological, and genetic and epigenetic approaches in a variety of crops, such as potato (Solanum tuberosum), poplar (Populus tremula), wheat (Triticum aestivum), tomato (Solanum lycopersicum), canola (Brassica napus var. napus), and cotton (Gossypium hirsutum).

Why did you study biology and when did you decide to do plant research?

In high school, my main interests were biology, chemistry, and mathematics. Although my father urged me to study mathematics, I chose the interdisciplinary field of biology because I was captivated by theories on evolution and the genetic basis of life. The complexity and diversity of life were fascinating and I was passionate about nature and its preservation. Moreover, alarmed by the industrial expansion of the harbor of Antwerp threatening the rural land near my hometown, Beveren, I became concerned about agriculture and

Abbreviations used in this paper: bar, bialaphos resistance; Bt, Bacillus thuringiensis; npt, neomycin phosphotransferase; PGS, Plant Genetic Systems.

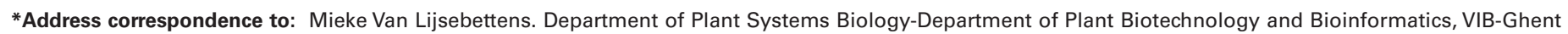
University, Technologiepark 927, B-9052 Gent, Belgium. Tel.: +32 9 3313970; Fax: +32 9 3313809. e-mail: milij@ psb.ugent.be
} 

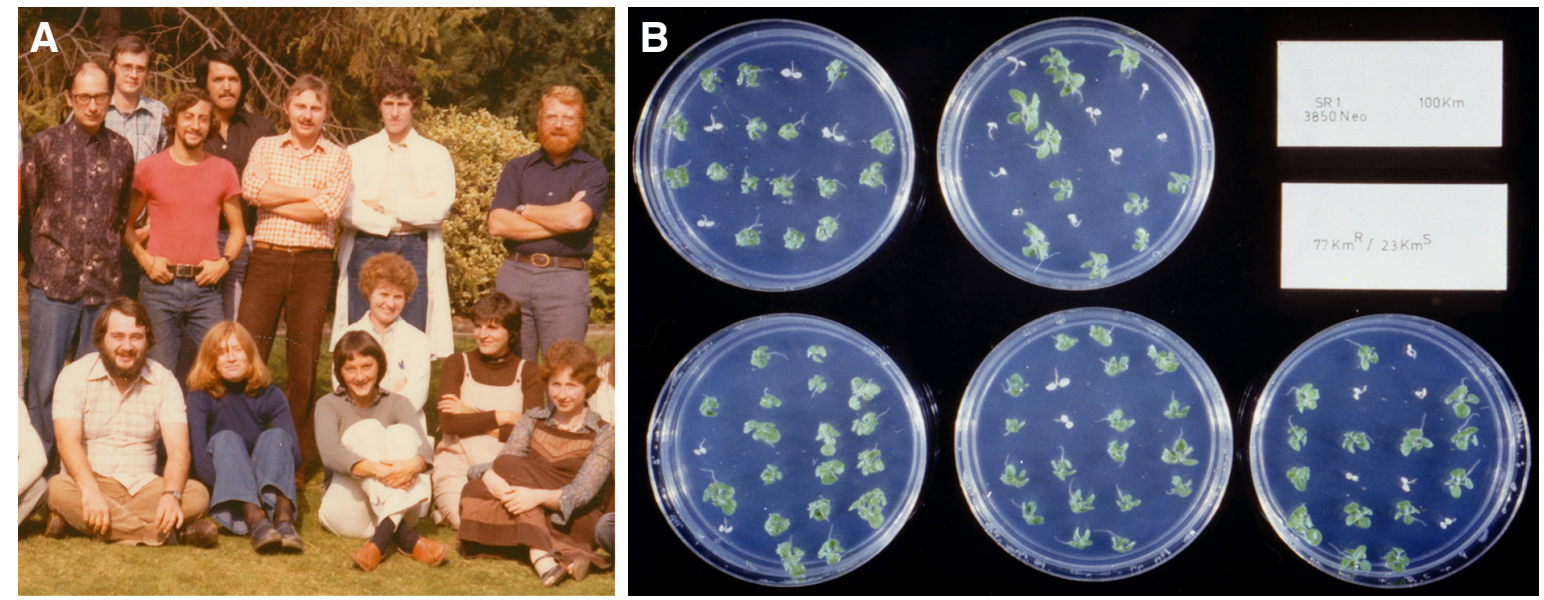

Fig. 1. Research at the Department of Genetics of Ghent University. (A) Marc De Block (standing, second from the right) together with Marc Van Montagu (standing, first from the left), Jeff Schell (standing, last on the right), and colleagues in the Botanical Garden of the Faculty of Sciences in 1978. (B) Mendelian inheritance of the nptll gene in the first transgenic tobacco progenies upon germination on kanamycin-containing medium: green seedlings contain the nptll transgene, whereas white seedlings have no transgene (reproduced with permission from De Block et al., 1984; (O) Nature Publishing Group).

its imminent shortage. My Biology teacher was inspiring and, very early on, I was strongly attracted by laboratory research. During my graduate studies, I selected the physiological-biochemical aspects of Zoology rather than Botany, because at that time the courses in Genetics and Molecular Biology were uniquely part of the zoological curriculum. Two Professors, Lucien De Coninck, who gave the course in Evolution, and Professor Jozef Schell, who taught Genetics, stimulated me to think "out of the box" and made me aware of the "Club of Rome". This institution was founded in 1968 by a group of independent scientists, business men, and politicians with a common concern for the future of humanity and the planet. Their reports predicted future shortages of food supplies for the ever-growing world population and motivated me to choose a profession that would allow me to solve agricultural problems related to food production. Hence, the subjects of my Masters dissertation (1977) and subsequent PhD thesis (1982) at the Department of Genetics in Gent (Faculty of Sciences) were the microbiological and genetic aspects of the Agrobacterium tumefaciens tumor-inducing ( $\mathrm{Ti}$ ) plasmid. At that time, the genetic basis of the Ti principle had just been discovered, namely that a part of the Ti plasmid, designated T-DNA, was transferred from the agrobacteria to the plant and incorporated into the plant genome. However, the plant research was limited to infection assays on potato and carrot (Daucus carota) slices and on pea (Pisum sativum) and tobacco (Nicotiana tabacum) seedlings to test the oncogenicity of agrobacteria containing the mutated Ti plasmids. The next step was to study the mechanisms of T-DNA integration, to develop vectors without oncogenes, to construct chimeric selectable marker genes with the ultimate goal to generate transgenic plants. Hence, my postdoc project was very ambitious: it aimed at generating the first transgenic plants into which chimeric selectable marker genes had been introduced.

\section{The first transgenic plants, did you succeed?}

As a postdoc, I collaborated with Dr. Patricia Zambryski (USA) and Luis Herrera-Estrella (Mexico), who had both joined the Department and who were developing Ti-plasmids in which the oncogenes had been removed and replaced by chimeric selectable markers. The research was instigated and coordinated by Professors Marc Van Montagu and Jozef Schell (Fig. 1A). My task was to set up the tissue culture aspects of the research, focusing on the transformation of plant protoplasts and selection of transformed callus initially by means of hormone-free medium (in the case of oncogenic T-DNAs) and, subsequently, by using methotrexate, chloramphenicol, or kanamycin as selectable markers. A three-week course in tissue culture techniques organized by Fred Meins, Pat King, and Ingo Potrykus at the Friedrich-Miescher Institute in Basel (Switzerland), in addition to a training in Otto Schieder's laboratory at the Max Planck Institute in Cologne (Germany), were key to gain insight into protoplast regeneration and tissue culture techniques, which I immediately implemented in my research. In 1983, I successfully obtained the first transgenic calli, transformed with an oncogenic T-DNA containing the methotrexate resistance marker (HerreraEstrella et al., 1983), at the same time as competing groups in the USA that had succeeded in obtaining transgenic calli transformed with the neomycin phosphotransferase gene (nptII) (Bevan et al., 1983; Fraley et al., 1983) - a historical momentum because scientists realized that the first hurdle had been eliminated in the race to transgenic plants. As a consequence, the next year, in 1984, I published an article on the transformation of plant protoplasts with the nononcogenic, npt/l gene-containing Ti plasmid, pGV3850, and their regeneration into transgenic shoots transformed with the nptll gene on kanamycin-containing medium; inheritance of the transgene was demonstrated by Mendelian segregation of the progenies (De Block et al., 1984) (Fig. 1B), in the same year as a group in the USA (Horsch et al., 1984).

\section{Why did you leave the academic world and join the start-up company Plant Genetic Systems?}

In 1982, Plant Genetic Systems (PGS) was founded as a start-up company. It was an initiative of Professsor Marc Van Montagu and a number of investors who wanted to generate transgenic plants with improved agriculture traits. At that time, Marc Zabeau, who was in charge of the company together with Marc Van Montagu, convinced me to leave the University and start working in PGS to further develop the plant transformation technology for different 
selectable markers, in various crops, and by using a variety of explants. The mission was very challenging because of the small scale (only 25 employees at that time) of the working environment and the serious competition of more established companies, such as Monsanto. However, we all had a pioneering spirit and were very determined to go for it, sometimes working day and night to be able to file patent applications in time. For many years, the company was steered by Jan Leemans and Walter De Logie, both scientists with a feeling for entrepreneurship and with a vision to recruit people and design innovative approaches and projects (Fig. 2A). One of the first targets of the company was to engineer insect tolerance by overproduction of Bacillus thuringiensis $(B t)$ insecticidal proteins. Besides the development of the Bt toxin resistance marker (Vaeck et al., 1987), the bialaphos (phosphinothricin analog) resistance (bar) gene of Streptomyces hygroscopicus (Thompson et al., 1987) was engineered as a herbicide resistance marker in plants. I introduced it into tobacco, potato, tomato, and poplar (Fig. 2B). To this end, I had to establish the glufosinate selection in tissue culture, to design assays to analyze progeny segregations and to measure enzymatic activities (De Block et al., 1987). Thanks to its wide concentration range for selection, its well-defined target (glutamine synthetase), and its available enzymatic assays, the bar gene turned out to be a versatile selection marker in various species, such as cereal crops, in which the npt/l selectable marker gene was inefficient. Hence, the bargene became a generally used selectable marker for plant transformation. Athird accomplishment at PGS was the introduction of male sterility in plants (Mariani etal., 1990) by expression of the Bacillus amyloliquefaciens ribonuclease (barnase) gene by means of the TA29 tapetum-specific promoter (kind gift from Robert B. Goldberg, University of California, Los Angeles), in addition to the ribonuclease inhibitor gene barstar for fertility restoration (Mariani et al., 1992) (Fig. 2C). Together, both genes provided a genetic system for hybrid seed production in crops. Furthermore, I transformed oilseed rape (canola) (De Block et al., 1989) that was used to introduce the bar and malesterility genes barnase and barstar and to generate the first canola hybrids. Meanwhile, another staff member at PGS, Henk Joos, developed the canola breeding. The first hybrid genotypes were commercialized in 1997 and were among the first successes of plant biotechnology.

\section{How important is transgene technology for the improvement of crops?}

Classical breeding, molecular breeding (genome-wide assisted selection), TILLING libraries (collection of lines containing point mutations), and targeted mutagenesis of endogenous plant genes through transgene technology will only improve crops to a certain level because they rely on the endogenous or population gene pools. However, transgene technology recruits genes from other organisms, such as algae, bacteria, or distantly related plants, to overcome species or outcrossing barriers and, thus, enlarge the gene pools in crops. Simple Mendelian agronomic traits might be improved by the introduction of single genes, such as herbicide resistance and insect resistance. Examples are the overexpression of the 5-enolpyruvylshikimate-3-phosphate synthase and bar genes that introduced resistance into plants against glyphosate (Roundup $\AA$, Monsanto) (Shah et al., 1986) and glufosinate (Basta ${ }^{\circledR}$, Bayer), respectively (De Block et al., 1987). Thus far, the greatest success story of biotechnology has been the engineering of crops with $B t$ insecticidal proteins. Indeed, for example, yearly massive yield losses were caused by the European corn borer (Ostrinia nubilalis) and the cotton bollworm (Helicoverpa zea) that damage the stalks and ears, and the flowers, respectively. The engineering of $\mathrm{Bt}$ proteins that are insecticidal by targeting a receptor specific for the insect gut diminishes its permeability and causes insect lethality, with a huge yield gain and reduction in insecticide spraying as a consequence (see Cover). Bt corn and Bt cotton have been commercialized for many years by several companies and represent the majority of the acreage produced worldwide. Refuge areas next to or within the Bt crop fields are part of good agricultural practice and $B t$ crops are engineered with a
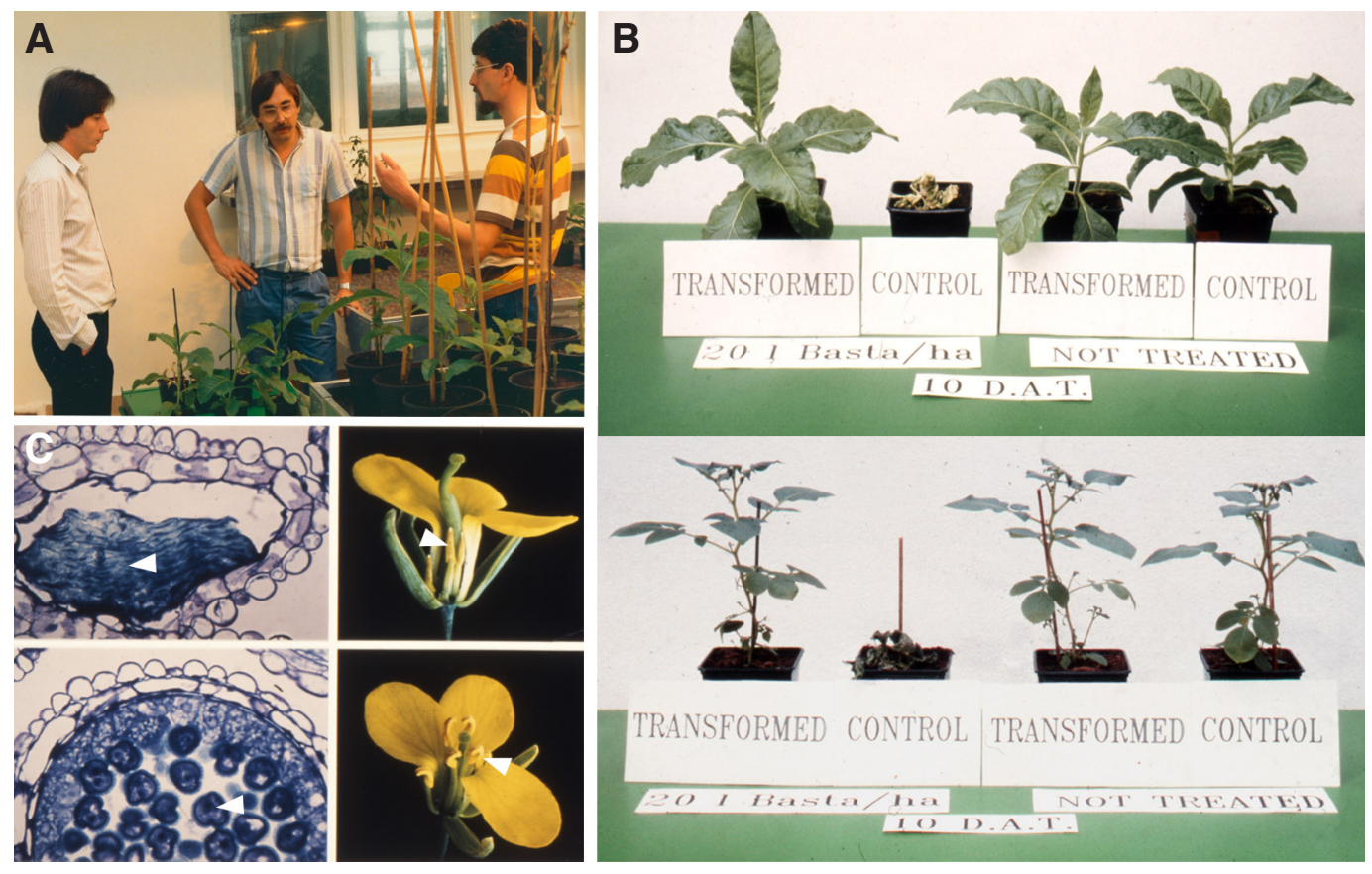

Fig. 2. Research at the Plant Genetic Systems (PGS) start-up company. (A) Marc De Block (right), Jan Leemans (middle), and Marc Vaeck (left) in the

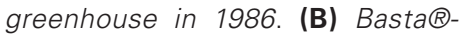
resistant versus Basta $\Theta$-sensitive tobacco (top) and potato (bottom) plants transformed with the bar gene (reproduced with permission from De Block et al., 1987; O Nature Publishing Group). (C) Male sterility in canola by overexpression of the barnase gene and restoration of fertility by the barstar gene. Top right, defective anthers (indicated by arrowhead); top left, lysed pollen in defective anther (indicated by arrowhead); bottom right, restoration of fertility (wild-type anthers, indicated by arrowhead); and bottom left, healthy pollen in anther restored to wild type (indicated by arrowhead) in barnase-containing lines with the restorer barstargene (reproduced with permission from Mariani et al., 1992; (c) Nature Publishing Group). 

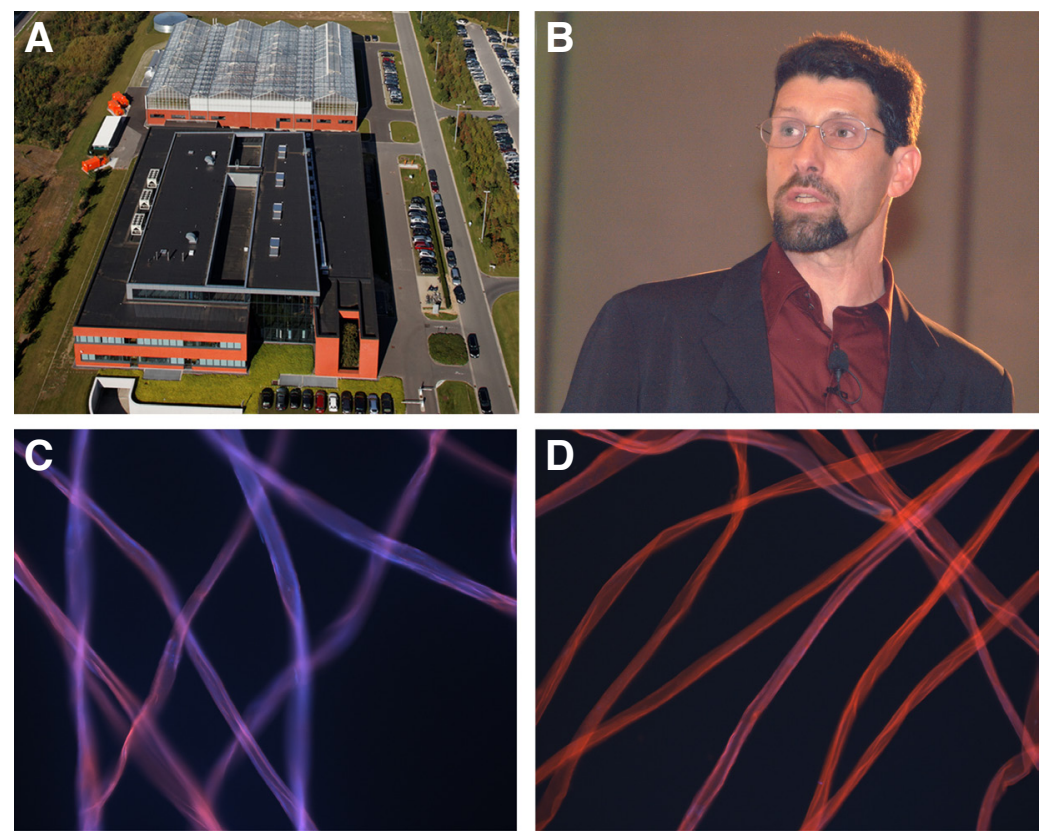

Fig. 3. Research at the Bayer CropScience Innovation Centre. (A) Bayer CropScience Innovation Centre at Gent. (B) Marc De Block giving a presentation at the Bayer Science Forum Symposium (2003, Monheim, Germany). (C) Control cotton fiber and (D) transgenic cotton fiber engineered with chitin, stained with Congo red, and visualized under ultra-violet light.

combination rather than with a single $B t$ gene - together these strategies lower the mutation rate to resistant insects and maintain insect diversity.

What new traits are to be expected from transgene technology?

New enzymes or entire pathways will be introduced into crops that will result in novel qualitative traits, such as altered starch, oil composition, or fiber structure. For example, the conversion of the nonreactive cotton fiber, consisting mainly of inert cellulose, to a reactive fiber is one of the ongoing projects in the Bayer CropScience Innovation Centre (Fig. 3). The strategy is to incorporate into the fiber walls positively charged anchors, such as chitin or chitosan-like molecules, that allow efficient staining with anionic dyes, as illustrated by Congo red staining (Figs. $3 \mathrm{C}$ and $3 \mathrm{D}$ ). This engineered fiber will lead to new applications and reduce the environmental impact, because less dye and less water will be needed in the production of fabrics.

Complex traits are features of which the properties are controlled by many genes. Their inheritance does not follow the simple rules of Mendelian genetics, because principally the relationship between genetic and phenotypic variations is nonlinear and environmental variation affects the phenotype. Complex traits, such as stress tolerance, yield, nutrient and water use efficiency, require the introduction of numerous genes that affect one or several pathways. Multiple transgenes have to be stacked preferentially in one genomic locus to simplify breeding and facilitate regulatory procedures. A good communication and integration will be needed between scientists and breeders to adjust the genetic background to novel transgene traits. Public perception and political decisions ought to be in favor of field trials to evaluate the amelioration of the complex traits under different environmental conditions and the commercialization of the improved products. As transgene technology is very expensive due to the regulatory costs, quality control of harvests, and field monitoring, it will be applied preferentially to crops with large acreage production or high-value yields. Typically, crops suitable for transgene application are maize (Zea mays), cotton, soybean (Glycine max), canola, wheat, and rice (Oryza sativa).

\section{What do you expect for the future?}

Knowledge gained by different approaches/disciplines, such as physiology, biochemistry, molecular and cell biology, genetics, epigenetics, and tissue culture, have to be more efficiently integrated in order to better define the critical parameters of complex traits. Personally, I think mathematics and computer science are the tools of choice. The multiple variables related to a complex trait have to be modeled to allow us to quantify and calculate the optimal parameter combinations to improve the trait. Mathematical modeling will be required to obtain a targeted experimental design rather than the "best-guess" design currently in use. The ultimate goal is to predict, for instance, yield by modification of a number of parameters (genes) for a specific genotype under certain environmental conditions. On average, it takes 15 to 20 years from the outline of a problem, design of the experimental

strategy, its implementation into the laboratory, further tests under field conditions, and, finally, production. This time frame is too long to cope with the current problems in agriculture caused by the changing climate (temperature and water), the increase of the world population, and the exhaustion of the world reserves of minerals and fossil fuel that are used to produce fertilizers. In my opinion, mathematical modeling will be an important tool to simplify and accelerate the whole process from defining the question to the commercialization of the improved product. Basic research will definitely remain essential to get insights into the biology of the plant and to unravel the molecular mechanisms underlying important agronomic traits. Furthermore, it will help also to make proper choices for gene engineering or allele selection.

\section{Acknowledgements}

We thank Jan Desomer for critical reading and suggestions and Karel Spruyt, Martine De Cock, and Griet Coussens for help in preparing the manuscript.

\section{References}

BEVAN, M. W., FLAVELL, R. B. and CHILTON, M.-D. (1983) A chimaeric antibiotic resistance gene as a selectable marker for plant cell transformation. Nature 304: 184-187.

DE BLOCK, M., HERRERA-ESTRELLA, L., VAN MONTAGU, M., SCHELL, J. and ZAMBRYSKI, P. (1984) Expression of foreign genes in regenerated plants and their progeny. EMBO J 3: 1681-1689.

DE BLOCK, M., BOTTERMAN, J., VANDEWIELE, M., DOCKX, J., THOEN, C., GOS SELÉ, V., MOVVA, R., THOMPSON, C., VAN MONTAGU, M. and LEEMANS, J. (1987) Engineering herbicide resistance in plants by expression of a detoxifying enzyme. EMBO J 6: 2513-2518.

DE BLOCK, M., DE BROUWER, D. and TENNING, P. (1989) Transformation of Brassica 
napus and Brassica oleracea using Agrobacterium tumefaciens and the expression of the bar and neo genes in the transgenic plants. Plant Physiol91: 694-701.

FRALEY, R. T., ROGERS, S. G., HORSCH, R. B., SANDERS, P. R., FLICK, J. S. ADAMS, S. P., BITTNER, M. L., BRAND, L. A., FINK, C. L., FRY, J. S., GALLUPPI, G. R., GOLDBERG, S. B., HOFFMANN, N. L. and WOO, S. C. (1983) Expression of bacterial genes in plant cells. Proc Natl Acad Sci USA 80: 4803-4807.

HERRERA-ESTRELLA, L., DE BLOCK, M., MESSENS, E., HERNALSTEENS, J.-P., VAN MONTAGU, M. and SCHELL, J. (1983) Chimeric genes as dominant selectable markers in plant cells. EMBO J 2: 987-995

HORSCH, R. B., FRALEY, R. T., ROGERS, S. G., SANDERS, P. R., LLOYD, A. and HOFFMANN, N. (1984) Inheritance of functional foreign genes in plants. Science 223: 496-498.

MARIANI, C., DE BEUCKELEER, M., TRUETTNER, J., LEEMANS, J. and GOLDBERG, R. B. (1990) Induction of male sterility in plants by a chimaeric ribonuclease gene. Nature 347: 737-741
MARIANI, C., GOSSELE, V., DE BEUCKELEER, M., DE BLOCK, M., GOLDBERG, R. B., DE GREEF, W. and LEEMANS, J. (1992) A chimaeric ribonuclease-inhibitor gene restores fertility to male sterile plants. Nature 357: 384-387.

SHAH, D. M., HORSCH, R. B., KLEE, H.J., KISHORE, G. M., WINTER, J. A., TUMER, N. E., HIRONAKA, C. M., SANDERS, P. R., GASSER, C. S., AYKENT, S. SIEGEL, N. R., ROGERS, S. G. and FRALEY, R. T. (1986) Engineering herbicide tolerance in transgenic plants. Science 233: 478-481.

THOMPSON, C. J., RAO MOVVA, N., TIZARD, R., CRAMERI, R., DAVIES, J. E. LAUWEREYS, M. and BOTTERMAN, J. (1987) Characterization of the herbicide resistance gene bar from Streptomyces hygroscopicus. EMBO J 6: 2519-2523.

VAECK, M., REYNAERTS, A., HÖFTE, H., JANSENS, S., DE BEUCKELEER, M. DEAN, C., ZABEAU, M., VAN MONTAGU, M. and LEEMANS, J. (1987) Insect resistance in transgenic plants expressing modified Bacillus thuringiensis toxin genes. Nature 328: 33-37.

\title{
Further Related Reading, published previously in the Int. J. Dev. Biol.
}

Relationship between brassinosteroids and genes controlling stomatal production in th Sonia Fuentes, Roberto C. Cañamero and Laura Serna Int. J. Dev. Biol. (2012) 56: 675-680

\author{
Evolution and pleiotropy of TRITHORAX function in Arabidopsis \\ Zoya Avramova \\ Int. J. Dev. Biol. (2009) 53: 371-381
}

Arabidopsis monomeric G-proteins, markers of early and late events in cell differentiation Mariette Bedhomme, Chantal Mathieu, Amada Pulido, Yves Henry and Catherine Bergounioux Int. J. Dev. Biol. (2009) 53: 177-185

Alteration of the shoot radial pattern in Arabidopsis Thaliana by a gain-of-function allele of the class III HD-Zip gene INCURVATA4

Isabel Ochando, Santiago González-Reig, Juan-José Ripoll, Antonio Vera and Antonio Martínez-Laborda

Int. J. Dev. Biol. (2008) 52: 953-961

Historical perspectives on plant developmental biology Mieke Van Lijsebettens and Marc Van Montagu

Int. J. Dev. Biol. (2005) 49: 453-465

5 yr ISI Impact Factor $(2011)=2.959$
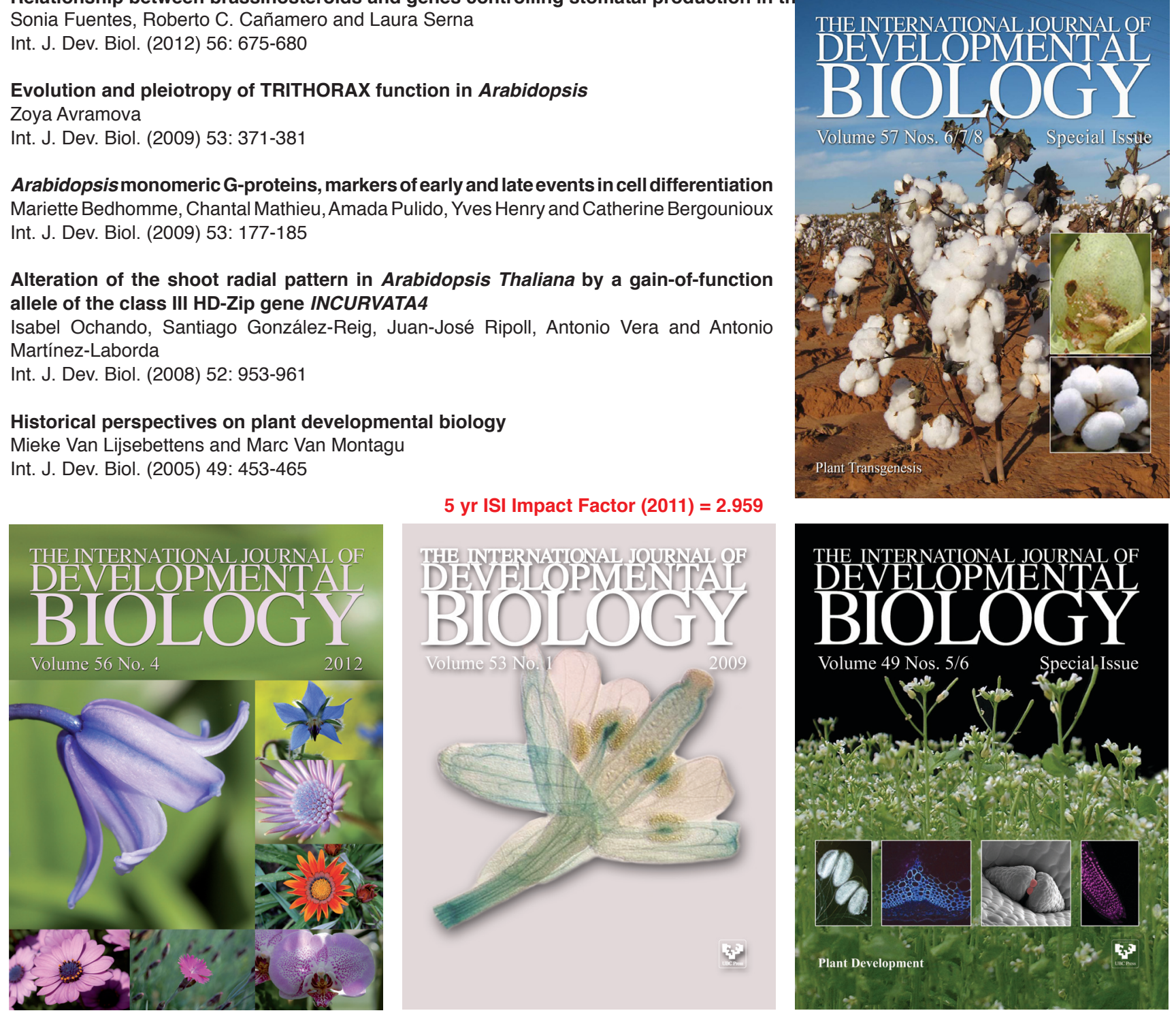